\title{
DEVELOPMENT OF NEW SOLUTIONS IN THE FIELD OF PRESENTATION AND PRESERVATION OF CULTURAL AND HISTORICAL HERITAGE IN THE NORTH+ REGION
}

\author{
Galina Bogdanova
}

g.bogdanova@gmail.com

Institute of Mathematics and Informatics

Bulgarian Academy of Sciences, Sofia, Bulgaria

\begin{abstract}
The accelerated development of interdisciplinary and digital technologies has prompted the need for continuous new research in all areas, including the preservation and presentation of cultural and historical heritage. This re-port examines and presents the activities of the project "Digital cultural treasure North +" with participation of Institute of Mathematics and Informatics, BAS, for improving access and dissemination of cultural heritage.

Some of the technological solutions developed in connection with the digital conversion of materials created in the digital center, the platform and the North+ network have been studied.

Keywords: Interdisciplinarity; Digital Technology; Cultural and Historical Heritage; Preservation; Representation; Digitization; Protection; Digital Center
\end{abstract}

\section{РАЗРАБОТВАНЕ НА НОВИ РЕШЕНИЯ В ОБААСТТА НА ПРЕАСТАВЯНЕТО И ОПАЗВАНЕТО НА КУАТУРНО- ИСТОРИЧЕСКОТО НАСАЕАСТВО В РЕГИОН СЕВЕР+}

Галина БогАанова

Институт по математика и инфоорматика

Българска акалемия на науките, София, България

Резюме: Ускореното развитие на интерАисциплинарните и цифровите технологии Аоведе $о$ необходимостта от непрекъснати нови изслеАвания във всички области, вкАючително и при опазването и представянето на културно-историческото наслеАство. Този АокАаА разглежАа и преАставя Аейности от проекта „Аигитално културно сък-ровище Север+" с участието на 
Института по математика и инорорматика към Българската акацемия на науките, за подобряване на Аостьпа и разпространението на културното наслеАство. РазглеАани са някои от технологичните решения, разработени във връзка с циоровото преобразуване на материали, създалени в цифрровия център, платфоормата и мрежата "Север+".

КАючови Ауми: Културно наслеАство; Метанаратив; Аигитализация; Метолология

В статия за Foreign Affairs К^аус Шваб, създате^ и председате^ на швейцарската организация World Economic Forum твьрди, че вече може Аа се говори за настьпването на Четвьртата индустриална революция, по време на която се прогнозира сливане на технологиите и размиване на границите межлу фоиическата, Аигиталната и биологическата сорери (Schwab, 2016). Ако прослеАим характеристиките на Индустриалните революции се вижла, че периодите им стават все по-къси и Третата, т.н. "Аигитална" инАустриална революция (Таблица 1) с бурното развитие на електрониката и инорормационните технологии вече се слива с настьпващата /настояща/ Четвьрта революция.

\begin{tabular}{|c|c|c|c|}
\hline ПериоА & $\begin{array}{l}\text { ИНАустрИवАни } \\
\text { революции }\end{array}$ & $\begin{array}{l}\text { Технологични } \\
\text { изобретения }\end{array}$ & $\begin{array}{c}\text { ПреАизвикани } \\
\text { резултати }\end{array}$ \\
\hline $\begin{array}{l}\text { 1760-1840 } \\
\text {-край на 18в. } \\
\text {-край на 19в. }\end{array}$ & Пьрва & $\begin{array}{l}\text { В произво сството } \\
\text { навлизат во Аата } \\
\text { и парната } \\
\text { енергия }\end{array}$ & $\begin{array}{l}\text { Механизиране на } \\
\text { производството }\end{array}$ \\
\hline $\begin{array}{l}1841 \\
\text {-край на 19в. } \\
\text {-среАа 20в. }\end{array}$ & Втора & $\begin{array}{l}\text { Поява на } \\
\text { електричеството }\end{array}$ & $\begin{array}{l}\text { Cьзаава се } \\
\text { масовото } \\
\text { произво Аство }\end{array}$ \\
\hline $\begin{array}{l}\text { срела на 20в. } \\
\text { Аосега начало } \\
\text { на } 21 \text { в. }\end{array}$ & $\begin{array}{l}\text { Трета } \\
\text { „Аигита^на }\end{array}$ & $\begin{array}{l}\text { Автоматизация } \\
\text { на } \\
\text { производството }\end{array}$ & $\begin{array}{l}\text { Развитие на } \\
\text { електрониката и ИТ }\end{array}$ \\
\hline
\end{tabular}




\begin{tabular}{|c|c|c|c|}
\hline ПериоА & $\begin{array}{c}\text { ИнАустриवлни } \\
\text { ревоАюции }\end{array}$ & $\begin{array}{l}\text { Технологични } \\
\text { изобретения }\end{array}$ & $\begin{array}{c}\text { ПреАизвикани } \\
\text { резултати }\end{array}$ \\
\hline $\begin{array}{l}\text { начало на } 21 \\
\text { век }\end{array}$ & $\begin{array}{l}\text { Четвьрта - } \\
\text { настьпваща }\end{array}$ & $\begin{array}{l}\text { С^иване на } \\
\text { технологиите }\end{array}$ & $\begin{array}{l}\text { Замьгляват се } \\
\text { ^иниите межлу } \\
\text { оизическата, } \\
\text { дигиталната и } \\
\text { биологическата } \\
\text { сорери }\end{array}$ \\
\hline
\end{tabular}

Таблица 1. ИнАустриални революции

В навечерието на Четвъртата индустриална революция интерАисциплинарните науки и цифровите технологии се развиват много АИнамично в почти всички сорери на човешкия живот. Развитието на цифровите технологии за опазване и прелставяне на културното историческото наслеАство (КИН) И политическите Аокументи на ЕС , насочени към цифрровизацията на културното наслеАство преАоставиха нови различни възможности (Todorov \& Noev, 2014) и съзАа $А$ иха Аобри практики (Bogdanova et al., 2010), (Ivanova et al., 2015), (Ivanova et al., 2014), (Noev, 2016), (Sotirova et al., 2012), (Sotirova et al., 2011). В настоящия Аоклал се представят някои реализирани изследвания по проект ${ }^{2}$ по програма БГ08 „Културно наслеАство и съвременни изкуства“, имаща за це^ "Аа се постигне по-широко участие в Аигитализацията и популяризирането на българското културно наслеАство в европейския контекст на културни и креативни индустрии, културен обмен, културно многообразие и др.". Аигитален центьр и мрежа „Север+".

1 Digital solutions in the field of cultural heritage [https://www.interregeurope.eu/, (Last view: 01.04.2019)], A Policy Brief from the Policy Learning Platform on Environment and resource, The Interreg Europe programme, 2018 [https://www.interregeurope.eu/fileadmin/user upload/plp uploads/policy b riefs/2018-08-06_Policy_brief_on_digital_technologies.pdf, (Last view: $01.04 .2019)]$

2 Проект "Аигитална културна съкровищница "Север+": Аокументиране, запазване и предоставяне на широк обществен Аостьп Ао културното наследство на библиотеки, музеи, архиви, галерии в Северна и Централна България. Инорормационен сайт на проекта http://bgseverplus.eu/bg/, (Last view: 01.04 .2019 ) 
По проект „Аигитална културна съкровищница „Север+" бяха съзаалени съвременен центьр за циоровизация (Аигитален центьр "Север+") и мрежа межАу сродни културни институции и организации от Централен северен район на България (регион Север+).

Проектът позволи обединяване на усилията за поставената цел опазването и цифровизирането на културното и Аокументално наследство на културните институции от региона.

Чрез технологична база на Аигитален центьр „Север+" и с помощта на технологичните партньори бе реализирана Аигиталната конверсия на специализираните колекции на неАвижимото културно наслелство на библиотеки, галерии и музеи (носители на съдьржание) от регион "Север+".

\section{Партньори в Север+ и техните роли:}

1. РНБ „П. Р. Славейков" - ВТ; бенифециент по проекта; носител на култ. СъАьржание

2. ИМИ-БАН - Велико Търново и София - технологичен партньор

3. Центьр "Амалипе" - Велико Търново - носител на културно сьдьржание

4. АКТ- Аирекция „Култура и туризьм“ - носител на културно сьдьржание

5. РИМ - ВТ - носител на културно съАьржание

6. РБ „Аюбен Каравелов" - Русе - носител на културно съдьржание

7. НЧ „Съгласие - 1869" - САивен - носител на културно съдьржание

8. НЧ „Зора 1860“ - Плевен - носител на културно сьАьржание

9. ПБНЧ „ЕАенка и Кирил А.Аврамови - 1856" - Свищов - носител на култ. СьАьржание

10. НАБИС - София - технологичен партньор

11. ОБ "George Baritiu" - Брашов- Румьния - носител на културно сьльржание

За осъществяване на поставената цел експертите от институциите 01-11 реализираха 21 модула със залачите, представени в табл. 2 (син маркер, ако институцията „Х“" е участвала в Аейност „У“"). 


\begin{tabular}{|c|c|c|c|c|c|c|c|c|c|c|c|}
\hline $\begin{array}{l}\text { Наименование на } \\
\text { Аейността }\end{array}$ & 01 & 02 & 03 & 04 & 05 & 06 & 07 & 08 & 09 & 10 & 11 \\
\hline $\begin{array}{l}\text { 1. Управление и } \\
\text { мониторинг на проекта }\end{array}$ & $X$ & & & & & & & & & & \\
\hline $\begin{array}{l}\text { 2. Проучване на } \\
\text { съществуващите } \\
\text { технологии за } \\
\text { дигитализация на } \\
\text { предвилените по проекта } \\
\text { обекти }\end{array}$ & $\bar{x}$ & $\bar{x}$ & & & & & & & & & \\
\hline $\begin{array}{l}\text { 3. Проучване и } \\
\text { детайлизиране на } \\
\text { наличните } \\
\text { специализирани колекции }\end{array}$ & $\bar{x}$ & $\bar{x}$ & $\bar{x}$ & $\bar{x}$ & $\bar{x}$ & $\bar{x}$ & $\bar{x}$ & $\bar{x}$ & $\bar{x}$ & $x$ & $x$ \\
\hline $\begin{array}{l}\text { 4. Залание и организация } \\
\text { на закупуване на } \\
\text { хардуерно и софтуерно } \\
\text { оборудване }\end{array}$ & $x$ & $x$ & & & & & & & & & \\
\hline $\begin{array}{l}\text { 5. Проучване и избор на } \\
\text { стандарти за изготвяне } \\
\text { Аигитални копия на реални } \\
\text { обекти и анотирането им } \\
\text { с метаданни }\end{array}$ & $\bar{x}$ & $\bar{x}$ & & & & & & & & & \\
\hline $\begin{array}{l}\text { 6. ИзгражАане на } \\
\text { дигитални центрове }\end{array}$ & $x$ & & $x$ & $x$ & $x$ & $x$ & $x$ & $x$ & $x$ & $\bar{x}$ & \\
\hline $\begin{array}{l}\text { 7. Обучение на екипите по } \\
\text { Аигитализация, сканиране, } \\
\text { фотозаснемане, 3D, } \\
\text { метаданни }\end{array}$ & $x$ & $x$ & $x$ & $x$ & $x$ & $x$ & $x$ & $x$ & $x$ & $x$ & $x$ \\
\hline $\begin{array}{l}\text { 8. Изграждане на масиви } \\
\text { с метаданни }\end{array}$ & $\bar{x}$ & & & $\bar{x}$ & $\bar{x}$ & $\bar{x}$ & $\bar{x}$ & $\bar{x}$ & $\bar{x}$ & & \\
\hline $\begin{array}{l}\text { 9. Аигитализиране } \\
\text { колекциите на РИМ - } \\
\text { Велико Търново } \\
\end{array}$ & & & & & $x$ & & & & & & \\
\hline $\begin{array}{l}10 \text {-13. Аигитализиране } \\
\text { колекциите в библиотеките } \\
\text { в Свищов Плевен Сливен } \\
\text { Русе }\end{array}$ & & & & & & $x$ & $x$ & $x$ & $\bar{x}$ & & \\
\hline $\begin{array}{l}\text { 14. Аигитализиране } \\
\text { архивен фоонд } \\
\text { „НеАвижимо културно } \\
\text { наследство“ на Аирекция } \\
\text { „Култура и туризьм“" }\end{array}$ & & & & $x$ & & & & & & & \\
\hline
\end{tabular}




\begin{tabular}{|c|c|c|c|c|c|c|c|c|c|c|c|}
\hline $\begin{array}{l}\text { Наименование на } \\
\text { Аейността }\end{array}$ & 01 & 02 & 03 & 04 & 05 & 06 & 07 & 08 & 09 & 10 & 11 \\
\hline $\begin{array}{l}\text { 15. Аигитализиране } \\
\text { колекциите на РБ „П. Р. } \\
\text { Славейков" - Велико } \\
\text { Тьрново }\end{array}$ & $x$ & & & & & & & & & & \\
\hline $\begin{array}{l}\text { 16. Обработка и } \\
\text { систематизация на } \\
\text { цифррови архиви и } \\
\text { хранилища }\end{array}$ & & $X$ & & & & & & & & & \\
\hline $\begin{array}{l}\text { 17. Организация на } \\
\text { защитата на } \\
\text { специализирани цифррови } \\
\text { архиви }\end{array}$ & & $x$ & & & & & & & & & \\
\hline $\begin{array}{l}\text { 18. Сьзааване на } \\
\text { "тематични пьтеки“" }\end{array}$ & $x$ & $x$ & $x$ & $x$ & & & & & & & \\
\hline $\begin{array}{l}\text { 19. Разпространение и } \\
\text { промотиране на } \\
\text { резултатите от проекта }\end{array}$ & $x$ & $x$ & $x$ & $x$ & $x$ & $x$ & $x$ & $x$ & $x$ & $x$ & $x$ \\
\hline $\begin{array}{l}\text { 20. Полбор на избрани } \\
\text { цифрови колекции в за } \\
\text { Европейската цифрова } \\
\text { библиотека }\end{array}$ & $x$ & & & & & & & & & $X$ & \\
\hline $\begin{array}{l}\text { 21. Изготвяне на } \\
\text { интерактивна карта } \\
\text { „Културна съкровищница“ }\end{array}$ & $x$ & $X$ & & $X$ & & & & & & & \\
\hline
\end{tabular}

Таблица 2. Аейности на ИМИ-БАН в "Север+"

Екип от експерти на технологичния партньор ИМИ-БАН в „Север+“ участва в интердисциплинарни изследвания по сеАем от модулите (2, 4, 5, 16, 17, 18 и 21) на "Север+" (Ivanova et al., 2015), (Ivanova et al., 2014). Някои от залачите бяха съвместно реализирани с експерти в областта на КИН От РНБ и АКТ. ИНтерАИсципАинарните метоАи преА^ожиха еАно пошироко и зальлбочено разглежАане на КИН.

При съвместната работа по тези модули, специалистите от всяка област анализираха и синтезираха това, което всяка от отАелните области предлага и го интегрираха в цялостно интерАисциплинарно решение на поставените проблеми. 
Технологии, станАарти и изисквания 39 Аигитализация, харАуерно и софтуерно оборуаване

В резултат от проучванията по Молул 4. (Изготвяне на залание и организация на обществени поръчки за закупуване на хардуерно и софртуерно оборудване) и конкретните особености на залачите за изпьлнение са разгледани и избрани различни харАуерни и софртуерни технологии и методи за Аигитализация в зависимост от типа на фрайловете (текст, фоото, видео, аудио, 3D). Бяха закупени работни станции за Аигитализация за институциите (носителите на съдьржание), скенери и роботизиран скенер за книги Treventus в библиотека „П.Р. Славейков" - В. Търново. Първата в България роботизирана система за масова Аигитализация ScanRobot Mass Digitization System 2.0 е показана на фигура 1.

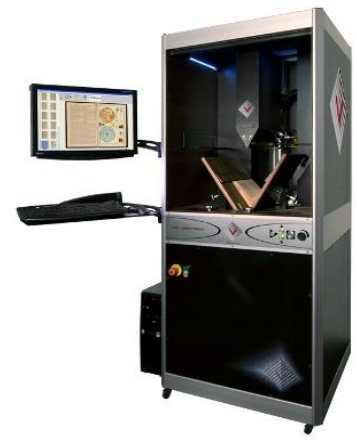

\section{Фигура 1. ScanRobot® - за Аигитализация на масиви от книги}

Експерти от ИМИ-БАН И РНБ реализираха заАачите по МоАул 2 (Проучване на съществуващите технологии за Аигитализация на предвилените по проекта обекти) и Модул 5 (Проучване и избор на стандарти за изготвяне Аигитални архивни копия на реални обекти и анотирането им с металанни).Изследваха се и анализираха съществуващите технологии в областта на запазване, Аигитализация и представяне на КИН. Бяха проучени различни хардуерни и софртуерни технологии за изгражАане на Аигитални хранилища и библиотеки и метоли за цифровизация в зависимост от типа медии (текст, фоото, 
аудио, вилео, 3D).Аигитализирането е процес на преобразуване на аналогова инорормация в цифров орормат. Резултатьт от цифрровизирането на артефактите са специфрични компютьрни файлове, отговарящи на опрелелени характеристики, различни за различните видове медии: изображения, текст, звук, вилео и Ар. За Аигиталната трансорормация се разгледаха и определиха съответни метоли и полхоли за цифрровизиране спореА типа медиа:

- Въвежлане на текстово съдьржание

- Сканиране с плоськ скенер

- Фотографоиране на Аокументи

- Технология за разпознаване на текст чрез OCR coфтуер

- Съзаване на цифрово аудио копие от аналогов запис

- Съзаяване на цифрово вилео копие от аналогов запис

- Съзаване на цифррови 3D (триизмерни) молели на обемни артефракти

- Цифрови обекти и фрайлови фрормати

Изследваха се изисквания за циоровизация спореА типа медиа (текст, фоото, вилео, аудио). Бяха анализирани особеностите на обектите за цифровизиране в Север+ и избрани различни детайли и варианти на указанията за цифровизиране за различните случаи на:

- Типове Аокументи

- Параметри за Аигитализиране

- Обработка на Аигитализираните Аокументи

- Комплектуване на файловете на Аигиталните обекти

- Именуване и полрежлане на фрайловете

- Вариант за книги

- Вариант за ръкописи

- Вариант за карти

- Вариант за ноти

- Вариант за периолика

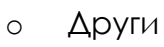

Избраните указания за Аигитализиране на визуални (печатни) материали за "Аигитална културна съкровищница „Север +"“ спореА съответните параметри и характеристики са описани подробно в Приложение 1 (с.36). 


\section{Организация на цифровите ресурси в Север+}

\section{и защитата им}

ЕКИПът на ИМИ-БАН И АКТ реализираха Аейността по МоАул 8 (Организация на цифровите архиви и хранилища). В резултат от изслеАванията на съществуващите технологии за Аървоволна файлова организация се реализира организация на архивите и хранилищата Север+. Отчетоха се особеностите при структурирането на Аокументалното и неАвижимо наслеАство в общо цифрово хранилище. Структурира се молел на общо цифррово хранилище за суровите необработени Аигитални образци от Аокументите, от който после $\Delta а$ се организират специалните колекции за Аигитален центьр за регион Север+.Проучена бе организацията на цифровите архиви и хранилища с цел по добро организиране на защита на архивите и тяхното сьльржание и съвременните технологии за осигуряване на защита на цифрови ресури. Суровите цифровизирани образци, както и обработените образци се организират в структури от обособени хранилища, архиви и колекции, в зависимост от виАа ИМ, използвайки основни структури и специфиични полструктори. Например суровите Аигитални фрайлове могат $а$ а се организират в слеАната структура (или Аруго поАхолящо структуриране):

Хранилище 1 (Архив 11 Колекция 111 Колекция 112

Архив 12 Колекция $121 \ldots)$

Хранилище 2 (Архив 21 Колекция 211 Колекция 212 ...)

Хранилище X (архивХ1 (колекцияХ 11, колекцияХ $12, \ldots)$, архив Х2,..)

Като образците от панелите се организират в отлелните хранилища, в които се обособяват отАелни архиви, спореА темите, в които се разполагат колекциите, като еАнотипните колекции с материали от различните фронАове ще се съхраняват в еАин общ архив.

Например Аигитален архив „РеАки и ценни старопечатни Книги в РНБ и читалищни библиотеки в регион Север+" може Аа включва ценните старопечатни книги от колекциите на различните библиотеки. Всяко 
Аигитално хранилище може да има и свои специфрични особености на структурата и организирането.

Колекциите на Аирекция „Култура и туризъм“ са структурирани и като в тематичните колекции. Аирекция „Култура и туризъм“ на община Велико Търново притежава местен специализиран архив за неАвижимото културно наслеАство, в който се съхраняват ценни книжни научни и технически Аокументи, показващи историята на проучването, техническото състояние и дейностите по консервация и реставрация на културните неАвижими обекти. Оригиналните чертежи и планове са изработени на хартия повечето чрез хелиографно изображение и заенно с останалите текстови и оротодокументи са нетрайни и застрашени от унищожение. Този ценен архивен оронл е предмет на Аигитална конверсия и е структуриран избрани тематични колекции в Аигиталното хранимище.Например:

\section{„НеАвижимо културно наслеАство в община В.Търново“"}

\section{Тема „Археологически резервати“}

- Колекция АМР „Царевец“

- Колекция АМР „Трапезица“

\section{Тема „Историческо селище Велико Търново“}

- Колекция „Архитектура на старите обществени сгради“

- Колекция "Архитектура на религиозните сгради“

- Колекция „Архитектура на старите жилищни сгради от ВъзражАането и слел Освобожлението"

- Колекция „Архитектурно и урбанистично развитие на граАа" /планове, Аокументи, стари снимки/

От размичните виАове архиви, могат $\Delta а$ се комбинират и организират АопьлнитеАно по избор избрани специални архиви, в които могат Аа участват най-разнородни материали, вк^ючени в различните хранилища, например:

- Аигитален архив „Именити български възрожАенци, свьрзани с регион Север" може Аа включва Аокументи и вещи от Аруги хранилища и архиви; 
- Аигитален архив "Мостовете по басейна на река Янтра“;

- Аигитален архив "Картички и снимки от регион Север+";

- Аигитален архив „Архитектурата през Вьзраждането в регион Север+".

На следващите фригури са представени моменти от работата по изграждането на масиви с метаданни сьс софртуерната система т "Север +" в $\triangle$ KT.

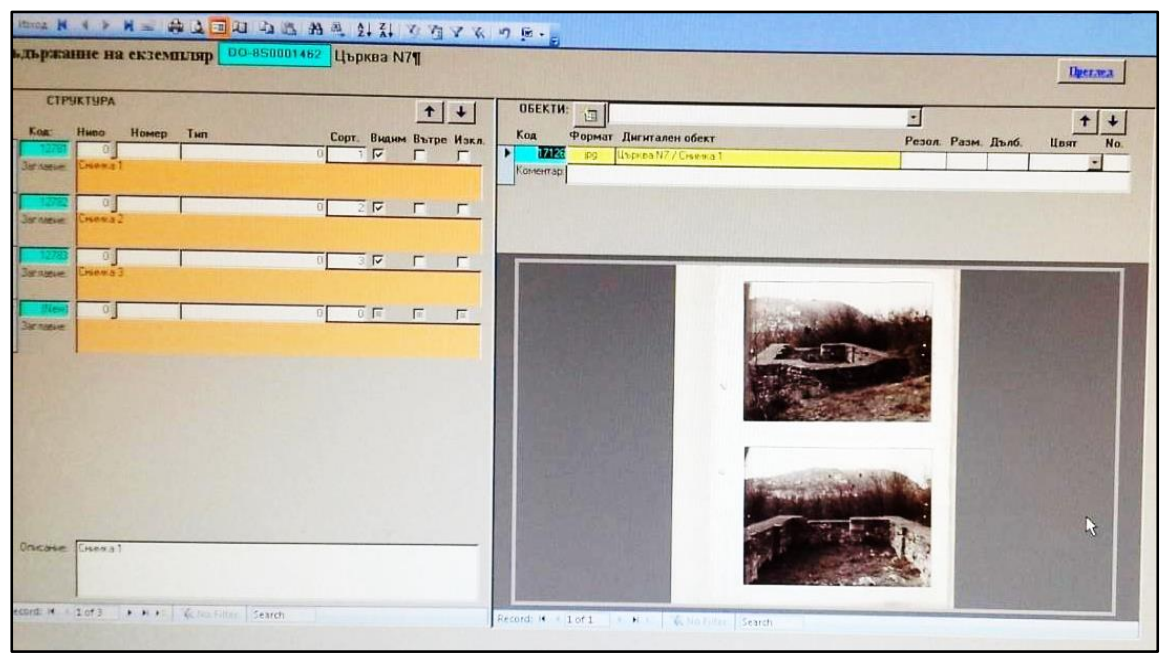

Фигура 2. Обект в системата на проект „Север+“

Цифрровизирани образци от колекциите в архивен фрон $А$ „НКН" по избраните стандарти в Аирекция „Култура и туризьм“ са представени на следващите фригури. 

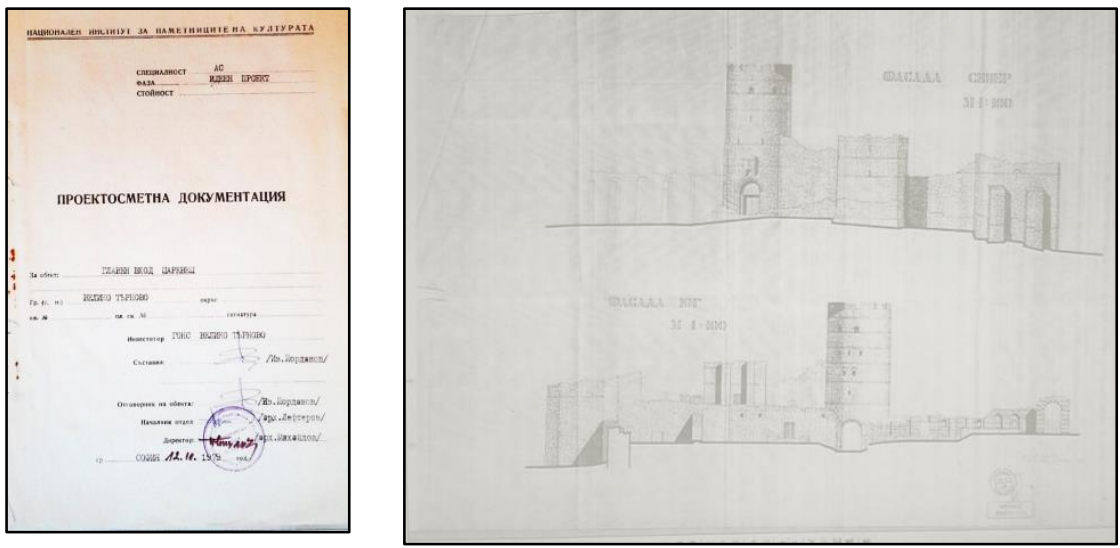

\section{Фигура 3. Цифрови обекти на Аокументи свързани с Царевец}

По Модул 17 (Организация на защитата на специализирани цифррови архиви се проучиха съществуващите софтуерни срелства за защита и изслеАвани възможностите за реализацията им в системата Север+. Бяха осигурени необхолимите предпазни мерки за хардуерна и софртуерна защита на Север+ на ниво Аигитални архиви и на ниво хранилища. За изображенията се разработиха специални поАхоли за защити с видим и с невидим воден знак чрез стеганографоски методи за защита на изображенията.

\section{Интерактивна карта, културни маршрути и каталог „Север+"}

За реализацията на интерактивната карта по Молу^ 21 от ИМИБАН са проучени интерактивните системи и сьвременните интерактивни технологии, както и съществуващи Аруги подобни разработки за интерактивни карти. Избрана е методика за създаването и е разработена интерактивна платорорма за картата на основата на Google map платорормата. В разработената срела е вк^ючена наличната Аигитална инорормация и културни обекти и пространства за община Велико Търново и регионите, свързани със съхраняваното културно съдьржание на партньорите по проекта Север+. 
Интерактивната културна карта Север+ се изработва и нанася на етапи и слоеве. Събрани са Аанни, измерени и уточнени GPS координатите, инорормация, роля и и Аейности в проекта за 11-те участващи институции в "Север+". В картата е отбелязано геоградрското местоположение на партньорите, културните обекти (GPS координатите), инорормация за тях и за Аигиталните им ресурси и както и Аруги на^ични Аанни и параметри за самите Аигитализирани обекти във всеки от тях. Аетай^ от менюто на интерактивната карта за 01РНБ е представен на фригура 4.

Специално за регион Север+ е разработен каталог с помощта на програмен продукт I-lib на фрирма Прима-Софрт (за представяне в Интернет на библиотечни и инорормационни бази от Аанни). Каталогът за Север+ представя културно-историческото наследство на широк регион от територията на Република България - колекции от Велико Търново, Свищов, Сливен, Плевен и Pусе (http://sever.libraryvt.com/ ).

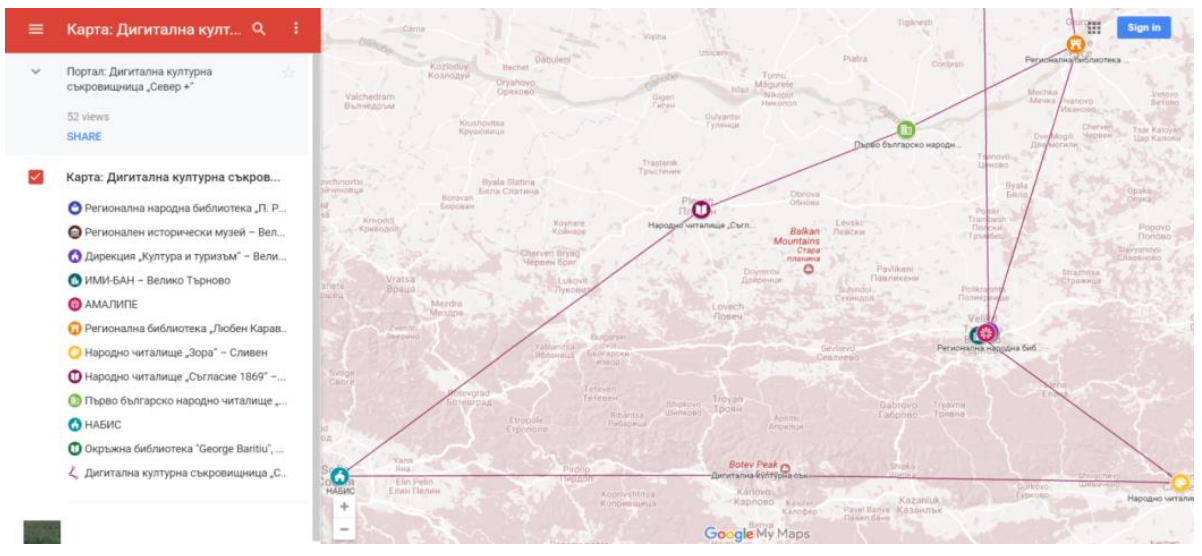

Фигура 4. Интерактивна карта „Север +” за 01 РНБ 


\section{Аитература / References}

Bogdanova, G.; Todorov, T.; \& Noev, N. (2010). Digitalization and security of "Bulgarian Folklore Heritage" archive. CompSysTech - 2010, vol. 471, ACM International Conference Proceeding Series (ICPS), 2010, 335-34

Ivanova, K.; Bogdanova, G.; \& Koleva, D. (2015). Interdisciplinary Studies for Digitization and Presentation of Collections of Cultural Heritage in "North+" Region. Digital Presentation and Preservation of Cultural and Scientific Heritage, 5, Special/2015, Sofia: Institute of Mathematics and Informatics at the Bulgarian Academy of Sciences, 2015, ISSN:1314-4006, 9-17 2015

Ivanova, K.; Bogdanova, G.; Zdravkov, K.; Paneva-Marinova, D.; \& Pavlov, R. (2014). Project "North +": Documenting, Preserving and Providing Public Access to the Cultural Heritage in Libraries, Museums, Archives and Galleries in North and Central Bulgaria. Proceedings of the International UNESCO Conference on Digital Presentation and Preservation of Cultural and Scientific Heritage, September 1821, 2014, Veliko Tarnovo, Bulgaria, 4, IMI-BAS, 2014, ISSN:1314-4006, 263-269 2014

Noev, N., (2016). Creation and presentation of knowledge from the field of cambology. Days of Science - 2016 - March Readings, Faber - Veliko Tarnovo, accepted for printing: 2016, ISSN: 1314-2283

Schwab, Klaus (2016). Fourth Industrial Revolution, Hermes, 240 p., 2016, ISBN:9789542616306, [https://m.helikon.bg/203528-Четвъртата-инАустриалнареволющия.html, (Last view: 01.04.2019)] // [К^аус Шваб, Четвьртата индустриална-революция, Хермес, 240 с., 2016]

Sotirova, K.; Peneva, J.; Ivanov, S.; Doneva, R.; \& Dobreva, M. (2012). Digitization of Cultural Heritage - Standards, Institutions, Initiatives, 23-68 pp. In: Access to Digital Cultural Heritage: Innovative Applications of Automated Metadata Generation, 2012, Plovdiv. ISBN: 978-954-423-722-6

Sotirova, K.; Ivanova, Kr.; \& Dobreva, M. (2011). Information Literacy in the Field of Digital Libraries. In: Proceedings from The IV National Conference "Education in the Information Society", Plovdiv 2011, 25-34 pp.

Todorov, T.; \& Noev, N., (2014). Technology of Three-Dimensional Scanning "Structured Light". In: Proceedings of Digital Presentation and Preservation of Cultural and Scientific Heritage - DiPP 2014, Veliko Tarnovo, Bulgaria, 18-21 September 2014, IV, 4, Institute of Mathematics and Informatics, BAS, 2014, ISSN: 1314-4006, 94 


\section{ПРИАОЖЕНИЕ 1: ИНСТРУКЦИИ}

за Аигитализиране на визуални (печатни) материали за "Аигитална културна съкровищница „Север + "“ спореА съответните параметри и характеристики

Типове Аокументи:периодични изАания, Книги, фотограффии, картички, плакати, брошури, карти, планове, чертежи и $А р$.

Параметри за Аигитализиране

- резолюция - използва се минимално 300 dрі, като ако Аокументьт е по-мальк от 5-6 см. по късата страна и/или има висока Аетайлност (напр. фротографрия с множество хора на нея) се използва резолюция от 400 или 600 dpi - по преценка спореА конкретния случай

- цветна Аьлбочина - с оглеА запазване оригиналния изглеА на Аокумента и улесняване визуалното му възприемане от потребителя печатни материали $А$ о 1944-45 г. се Аигитализират в цвят, 24-bit RGB. При по-нови (Съвременни) Аокументи се преценява - ако съдьржат цветни изображения, графрики, Аиаграми и т.н., то се Аигитализират с параметрите, описани по-горе. Ако не е необхолимо запазване на цвета, то се използва 8-bit Greyscale.

- фоайлов формат - Аигиталните обекти се запазват в архивен фрормат - TIFF без компресия.

\section{Обработка на Аигитализираните Аокументи}

Независимо от виАа на АОкумента всяка отАелна страница се запазва в самостоятелен фрайл, вк^. кориците, ако има такива. При фротографрии, картички, картини, карти и Ар. Аистови Аокументи се Аигитализира и гърба, ако на него има някакъв виА информация - текст, номерация, изображение, печат и т.н. Изображениято се изрязва по рьба на страницата, като се следи да няма загуба на съществена информация, особено при подвързаните оригинали (книги, периолика). Ако подвързията е прекалено стегната и част от текста се губи в сгъвката, изображението се изрязва по такьв начин, че в него да остане мала част (1-2 см) от съседната страница.

Всички страници трябва Аа бъдат вертикално полравнени (изправени).

Всички фрайлове се конвертират от TIFF в PDF с прилагане на компресия и запазване на 70 \% качество, като се съблюлават условията, описани по-Аолу.

Комплектуване на файловете. От значение за прави^ната работа на Аигиталната библиотека е коректното комплектуване на фрайловете на Аигиталните обекти:

- 3 п периолика: всяка голина/годишнина от Аалено заглавие се съхранява в самостоятелна папка, в нея страниците/фрайловете на всеки отАелен брой се съхраняват в отлелна папка, поАхолящо именувани (виж по-АОАу)

- за книги, рькописи, сборници и пр.: всяка книга се сьхранява в самостоятелна папка. Ако има случай на поАвързани няколко Книги в общо тя^о, но инорормационно различни, несвързани помежАу си, то всяка от тях трябва $А а$ бъле съхранявана в отлелна папка.

- $\quad$ за албуми и атласи - преценява се спорел типа сьльржание.

- $\quad$ за листови материали: съхраняват се, подходящо именувани, в обща папка за типа Аокументи. Ако межАу тях има такива, които попадат в серия, поредица или са свързани по някакъв Аруг признак, то те се обособяват в самостоятелна полпапка. 


\section{Именуване и подрежАане на файловете}

Всички фрайлове трябва да получат имена по определена конвенция (схема). Описаната по-Аолу се отнася за крайния потребителски орормат, който ще бъле Аостьпен чрез Аигиталната библиотека. Ако архивните файлове (в TIFF фрормат) ще бъдат съхранявани в РНБ „П. Р. Славейков“ - Велико Търново, то същата конвенция важи и за тяхното подрежАане.

\section{Вариант за книги:}

Име на папка: [грал]-[институция]-[голина с 4 цифрри]-[кол - инвентарен номер или Ар.]-[име на книгата или разпознаваема част от него]

Име на фрай^: [грал]-[институция]-[голина с 4 цифрри]-[кол - инвентарен номер или $\Delta$ р.]-[име на книгата или разпознаваема част от него]_[брояч].pdf

[брояч]: 001, 002, 003......

В папката със страниците на книгата се поставя Аопьлнителен фрайл, който слелва приетата конвенция за именуване, има разширение .jpg и сьльржа корицата или заглавната страница на книгата - по преценка, изображението $а ~ а$ Аава разпознаваемост на книгата и в умален мащаб.

\section{Вариант за ръкописи:}

Име на папка: [грал]-[институция]-М-[година с 4 цифри]-[кол - инвентарен номер или Ар.]-[име на ръкописа или разпознаваема част от него]

Име на фрайл: [граА]-[институция]-М-[година с 4 цифри]-[коА - инвентарен номер или $\Delta$ р.]-[име на ръкописа или разпознаваема част от него]_[брояч].pdf

[брояч]: 001, 002, 003......

M - manuscripts, сигнатура за визуално разпознаване на папки и файлове на Аигитализирани рькописи

В папката със страниците на рькописа се поставя Аопьлнителен фрайл, който слелва приетата конвенция за именуване, има разширение .jpg и съдьржа корицата или заглавната страница- по преценка, изображението $\Delta а$ Аава разпознаваемост на Аокумента и в умален мащаб.

\section{Вариант за карти:}

Име на папка: [грал]-[институция]-МАР-[година с 4 цифрри]-[кол - инвентарен номер или Ар.]-[заглавие на картата или разпознаваема част от него]

Име на файл: [грал]-[институция]-МАР-[голина С 4 цифрри]-[коА инвентарен номер или Ар.]-[заглавие на картата или разпознаваема част от него]_[брояч].pdf

[брояч]: 001, 002, 003...... - използва се, ако картата е многостранична (ат^ас, и^и пьк на еАнолистова карта гърбът има значеща инорормация).

MAP - maps, сигнатура за визуално разпознаване на папки и файлове на Аигитализирани карти и^и ат^аси с карти

В папката със страниците на картата се поставя Аопьлнителен фрайл, който следва приетата конвенция за именуване, има разширение .jpg и сьльржа корицата или заглавната страница - по преценка, изображението Аа $а$ ава разпознаваемост на Аокумента и в умален мащаб.

\section{Вариант за ноти:}

- Име на папка: [граА]-[институция]-MN-[голина с 4 цифрри]-[коА - инвентарен номер или Ар.]-[заглавие на Аокумента или разпознаваема част от него]

- Име на фрайл: [граА]-[институция]-MN-[голина с 4 циори]-[коА - инвентарен номер или др.]-[заглавие на Аокумента или разпознаваема част от него]_[брояч].pdf 
- [брояч]: 001, 002, 003...... - използва се, ако партитурата е многостранична (албум, или пьк на еАнолистова партитура гърбьт има значеща инорормация). - $\quad$ MN - musical notes, сигнатура за визуално разпознаване на папки и файлове на Аигитализирани партитури или албуми/сборници с ноти

В папката със страниците на партитурата/албума/сбормика се поставя Аопьлнителен фрайл, който слелва приетата конвенция за именуване, има разширение .jpg и сьльржа корицата или заглавната страница- по преценка, изображението $А$ व $А$ ава разпознаваемост на Аокумента и в умален мащаб.

\section{Вариант за периодика:}

Име на папка: [грал]-[институция]-[година с 4 цифрри]-[коА - серия или Ар.][име на периодичното издание или разпознаваема част от него]

Име на фрайл: [граА]-[институция]-[коА - серия или Ар.]-[голина с 4 цифрри][име на периодичното издание или разпознаваема част от него]_[ брояч].pdf

[брояч]: 1, 2, 3......

В папката на съответната годишнина на периодичното изАание се поставя Аопьлнителен фрайл, който слеАва приетата конвенция за именуване, има разширение .jpg и съдьржа изображение - изрязано от заглавната част наименование на вестника/списанието.

Аруги: Име на папка (ако е необходимо): [град]-[институция]-[година с 4 цифри или Аиапазон]-[име на серията или каквото и $\Delta \mathrm{a}$ e]

Име на фрайл: [грал]-[институция]-[голина с 4 цифрри]-[име на Аокумента или разпознаваема част от него]_[ брояч].[xуz]

[брояч]: 1, 2, 3......

[xyz] - поАходящо фрай^ово разширение

Важно: Имената на файловете и папките се изписват зальлжително на ^атиница, като се спазва принципьт за транслитерация от националната азбука по официално утвърлена таблица за конверсия. Не се Аопускат интервали или символи, различни от букви и цифрри, с изключение на тире. Аумите при необходимост се разделят със средно тире: ".", Аолно тире ("-") се използва само при броячите в имената на файловете.Всички PDF файлове в папката на Аалена книга (рькопис, ноти, карти и пр.) трябва да бъдат с еАнакви имена, с изключение на брояча в края на името, който започва винаги от 001 (изключение правят Аокументи наА 1000 страници, при тях започва от 0001) и нараства

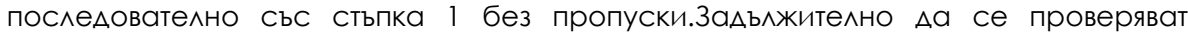
файловете за наличие и пореАност.

\section{Примери:Вариант за книги:}

VT-RNB-2004-1715-Nosiite-na-bulgarite-simvoli-i-tradicia

VT-RNB-2004-1715-Nosiite-na-bulgarite-simvoli-i-tradicia.jpg

VT-RNB-2004-1715-Nosiite-na-bulgarite-simvoli-i-tradicia_001.pdf

VT-RNB-2004-1715-Nosiite-na-bulgarite-simvoli-i-tradicia_002.pdf

VT-RNB-2004-1715-Nosiite-na-bulgarite-simvoli-i-tradicia_003.pdf

\section{Вариант за периодика:}

Pleven-Saglasie-3510-1924-Lozarski-pregled

Pleven-Saglasie-3510-1924-Lozarski-pregled.jpg

Pleven-Saglasie-3510-1924-Lozarski-pregled-1.pdf

Pleven-Saglasie-3510-1924-Lozarski-pregled-2.pdf

Pleven-Saglasie-3510-1924-Lozarski-pregled-3-4.pdf 


\section{КУАТУРНО-ИСТОРИЧЕСКО НАСАЕАСТВО: ОПАЗВАНЕ, ПРЕАСТАВЯНЕ, АИГИТААИЗАЦИЯ}

\section{CULTURAL AND HISTORICAL HERITAGE: PRESERVATION, PRESENTATION, DIGITALIZATION}

Научна пореАица: брой 1(6), гоАина V (2019)

Science series: volume 1(6), year V (2019)

\section{ISSN: 2367-8038}

\begin{tabular}{r|l} 
Релактори & Editors \\
Петко Ст. Петков & Petko St. Petkov \\
Галина БогАанова & Galina Bogdanova \\
Институт по математика и & $\begin{array}{l}\text { Institute of Mathematics and } \\
\text { информатика }\end{array}$ \\
Informatics \\
БАН, България & ВAS, Bulgaria
\end{tabular}

Материалите в сборника са обект на авторско право. Разрешава се безвъзмезАното ползване на техни електронни/ хартиени копия само

за лична употреба или с це^ обучение, при писмено указание за мипса на търговски намерения и пьлно цитиране на текста от тази

страница.

За копиране пол Аруга орорма, препубликуване или публикуване на сървъри се изисква писмено разрешение и/и^и заплащане.

() Авторски колектив, 2019

Технически реАактори: Нико^ай Ноев, гА. ас. А-р Калина Сотирова-Вълкова, ас. А-р
This work is subject to copyright. Open and free use of digital/ hard copies of publications is granted only for personal or educational use, while there are written statement for not-commercial intention and full citation of the text of the current page.

For any other reproducing types,

re-publishing, photocopying, recording, orany other storage retrieval system/server is required written permission and/or fee.

(C) Authors` Group, 2019

Technical editors:

Nikolay Noev, Assist. Prof. PhD Kalina Sotirova-Valkova, Assist. Prof. PhD 